\title{
Ларин А.Н., Сулейманов А.С. \\ Актуальность формирования саморегуляции поведения у курсантов военного института войск национальной гвардии на практических занятиях по физической подготовке
}

Пермский военный институт войск национальной гвардии Российской Федераџии (Россия, Пермь)

doi:10.18411/spc-22-10-2017-12

idsp: 000001:spc-22-10-2017-12

В системе воспитания курсантов национальной гвардии Российской Федерации непосредственно физическая подготовка представляет собой структурированную совокупность наиболее оптимальных педагогических способов и средств управляемого достижения целей обучения и воспитания будущих офицеров.

Почему так актуальна физическая подготовка курсантов национальной гвардии Российской Федерации?

Во первых, перед военной педагогикой многие сложные и важные задачи поставил Указ Президента Российской Федерации от 5 апреля 2016 года № 157 «Вопросы Федеральной службы войск национальной гвардии Российской Федерации». Решение этих задач связано не только с научным обоснованием особенностей процесса подготовки офицерских кадров, способных обеспечивать национальную безопасность нашего государства, но и с формированием такой системы образования, которая должна способствовать достижению приоритетных целей войск национальной гвардии Российской Федерации.

Во вторых, физическая подготовка представляет собой многокомпонентную систему, целостную, структурированную, состоящую из нескольких компонентов. А именно: интеллектуальную, мотивационную, эмоционально-волевую, практикоориентированную. И эта система имеет ярко выраженную динамику, которая находится в постоянном развитии. Эта система характеризует психофизическое состояние, которое возникает и становится свойством личности в результате интеграции интеллектуального, мотивационного, эмоционально-волевого и практикоориентированного компонентов.

Способности к обучению, уровень мотивации, волевой потенциал, физическая подготовленность, которые обеспечивают его продуктивную реализацию в профессиональной деятельности и дальнейшее саморазвитие - это есть критерии компонентов саморазвития курсантов национальной гвардии Российской Федерации.

Абульханова-Славская К.А. в своих трудах раскрывала проблемы саморегуляции. Опираясь на типологические разработки Д.Н.Узнадзе, Б.М.Теплова и др. и собственные эмпирические исследования, разработала типологическую стратегию изучения личности (метод прогрессивной типологии). На ее основе осуществлено исследование высших, связанных с жизненным путем, личностных способностей способности к организации времени, активности-инициативы, ответственности, интеграла притязаний, саморегуляции и удовлетворенности, сознания личности в целом. Разработала концепцию личностной организации времени жизни, раскрывающую трехкомпонентную структуру (осознание, переживание и практическая регуляция времени) и типологические особенности этой организации. Также, вопросами саморегуляции занималисьБ.Г.Ананьев, П.К.Анохин, Н.А.Бернштейн, А.Н.Леонтьев и др. [2]

Г.В.Буланова, Г.Ш.Габдреева, Э.3.Менделевич, Г.В.Шавырина. в своих научных исследованиях изучали психологические аспекты применения психической саморегуляции в учебном процессе [2].

Актуальность физической подготовки в целях формирования саморегуляции также состоит и в том, что в настоящее время очень остро стоит вопрос обеспечения 
образовательных организаций войск национальной гвардии Российской Федерации разработками, определяющими содержание дидактических и воспитательных основ подготовки будущих офицеров новой силовой структуры. Все это показывает острую необходимость в расширении количественного и качественного научного потенциала образовательных организаций войск национальной гвардии Российской Федерации. При решении этой задачи ориентироваться следует прежде всего на ведущих учёных и специалистов[1].

Представим структуру профессионального саморазвития в процессе физической подготовки курсантов в виде схемы.

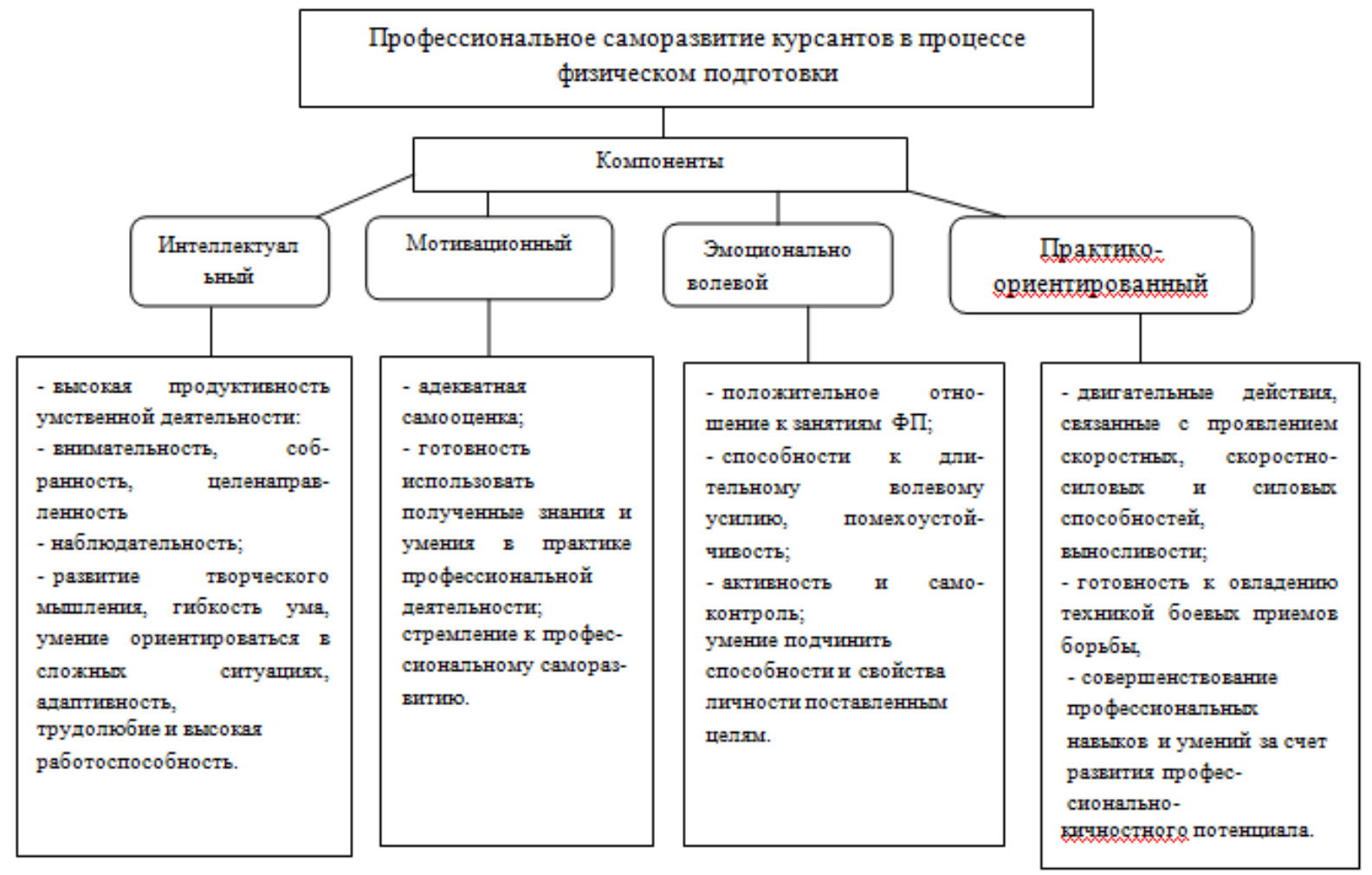

По мнению Слепова В.А. « в современном образовательном процессе войск национальной гвардии Российской Федерации, должна быть инновационная физическая подготовка курсантов, с такой подачей учебного материала, объединяющая и гуманитарные знания которая научила бы курсанта самостоятельно мыслить, способствовала формированию «знающего, ищущего, критического ума» [7]. Также в данном процессе, конечно, также не обойтись без усилий академической образовательной системы, которая может обосновать требования, отражающие состояние знаний о методологии познания и культуры будущего выпускника, необходимые для профессиональной карьеры, творчества и самореализации, и при этом быть настоящим патриотом своего государства и получать удовлетворение от служения Родине.

Таким образом, практические занятия по физической подготовкекурсантов военного института войск национальной гвардии способствуют продуктивную реализацию полученных знаний и умений в профессиональной деятельности и дальнейшее саморазвитие будущих офицеров.

1. Артёмов А. М., Туревский И.М. Динамика компонентов профессионального саморазвития курсантов в системе занятий физической подготовкой // Ученые записки.- 2010, №6.

2. Карсанов Э.Х. Профессиональная ориентация как педагогическое условие подготовки курсантов к самообразовательной деятельности. Вестник Санкт-Петербургского университета МВД России. 2010. 
3. Ларин А. Н. К проблеме саморегуляции в процессе физической подготовки курсантов военных институтов войск национальной гвардии Российской Федерации. / А. Н. Ларин, А. В. Дубровский, В. П. Чердынцев // Журнал «Современные проблемы науки и образования». - 2016, № 6. URL: https://www.science-education.ru/ru/article/view?id=25794.

4. Ларин А. Н. Моделирование саморегуляции поведения как средства повышения результативности физической подготовки курсантов военных институтов войск национальной гвардии Российской Федерации. / А. Н. Ларин, А. В. Дубровский // Мир образования - образование в мире.- 2017. -№1 (65). С 210-216.

5. О роли двигательной активности студентов гуманитарных вузов и способах ее повышения / А. А. Горелов [и др.] // Ученые записки университета им. П.Ф. Лесгаф- та. - 2009. - № 1 (47). - С. 28-33.

6. Подлипняк, Ю.Ф. Педагогические основы системы физической подготовки слушателей вузов МВД СССР :дис. ... д-ра пед. наук / Подплиняк Ю.Ф. - М., 1986. - 430 с.

7. Слепов В.А. Новая педагогика» в образовательных организациях войск национальной гвардии российской федерации // Вестник Санкт-Петербургского Университета МВД России.-2016.

\section{Лопсан-Ендан Ч.М. \\ Методика подготовки учащихся к ЕГЭ с помощью тестовых заданий с рисунками}

Тувинский государственный университет (Россия, Кызылл)

doi:10.18411/spc-22-10-2017-13

idsp: 000001:spc-22-10-2017-13

Один из способов достижения личностных, метапредметных и предметных результатов, запланированных ФГОСсреднего (полного) общего образования, проведение уроков учета, контроля знаний и умений, в ходе которых учащиеся соотносят теоретические знания и с их практическим применением, логически размышляют, сами делают выводы [5].

В связи с этим на учителя возлагаются очень ответственные задачи, главная из которых заключается в том, что именно на уроке учащемуся должны быть представлены все необходимые условия, которые обеспечили бы ему должное развитие. Каждый этап урока должен включать не просто необходимый набор содержания, удовлетворяющий целям и задачам урока, а набор приемов, методов, дидактических средств, способствующих активизации мыслительной деятельности, стимулирующих постоянное развитие учащихся. Таким образом, современному учителю важно уметь грамотно организовать учебный процесс, в котором основным методом и средством обучения становится химический эксперимент, именно он помогает в решении основных метапредметных и предметных результатов обучения [1].

Химико-педагогическое образование предполагает формирование у школьников отчетливых представлений о тесной связи между теоретическими знаниями и практическими умениями. С этой целью можно предложить учащимся тестовые задания с рисунками, в условиях которых описаны конкретные химические операции (действия), отражающие физические и химические свойства веществ. При решении учащиеся с помощью рисунков анализируют, осмысливают и объясняют, выбирают способы решения, а результатом служит осознание их личностной значимости: школьники видят пользу химического эксперимента на теоретическое знание.

На основании исследований $[2,3,4]$ нами разработаны тестовые задания с рисунками и составлены по аналогии с контрольно-измерительными материалами ЕГЭ. Каждый из вариантов состоит из двух частей. Задания части 1 предполагают задания на множественный выбор, установления соответствия и последовательности действий. Задания части 2 требуют подробного ответа на вопрос.

Цель предлагаемой методики помочь учащимся осознать сущность химического эксперимента и научить ориентироваться в свойствах веществ.Данная методика включает в себя два этапа: проведение химического эксперимента и тестирование. В тестировании предлагаем задания с рисунками о действиях и операциях, связанных с 